\title{
National Stable Isotope Baseline for Precipitation in Malawi to Underpin Integrated Water Resources Management
}

\author{
Limbikani C. Banda ${ }^{1, *}$, Michael O. Rivett ${ }^{2}$, Anold S. K. Zavison ${ }^{3}$, Sydney Kamtukule ${ }^{3}$ and Robert M. Kalin ${ }^{1}$ (D \\ 1 Department of Civil and Environmental Engineering, University of Strathclyde, Glasgow G1 1XJ, UK; \\ robert.kalin@strath.ac.uk \\ 2 GroundH2O Plus Ltd., Quinton, Birmingham B32 1DY, UK; rivett@groundh2oplus.co.uk \\ 3 Ministry Forestry and Natural Resources, Water Resources Department, Private Bag 390, \\ Lilongwe 3 30048, Malawi; anoldzavison@gmail.com (A.S.K.Z.); slkamtukule@gmail.com (S.K.) \\ * Correspondence: limbikani.chitsundi-banda@strath.ac.uk
}

Citation: Banda, L.C.; Rivett, M.O.

Zavison, A.S.K.; Kamtukule, S.; Kalin, R.M. National Stable Isotope Baseline for Precipitation in Malawi to Underpin Integrated Water Resources Management. Water 2021, 13, 1927. https://doi.org/10.3390/w13141927

Academic Editor: Frédéric Huneau

Received: 8 June 2021

Accepted: 9 July 2021

Published: 13 July 2021

Publisher's Note: MDPI stays neutral with regard to jurisdictional claims in published maps and institutional affiliations.

Copyright: (C) 2021 by the authors. Licensee MDPI, Basel, Switzerland. This article is an open access article distributed under the terms and conditions of the Creative Commons Attribution (CC BY) license (https:// creativecommons.org/licenses/by/ $4.0 /)$.

\begin{abstract}
With the resurgence of water-isotope tracing applications for Integrated Water Resource Management in developing countries, establishing a stable isotopic baseline is necessary. Developing countries, including Malawi, continue to struggle with the generation of consistent and long-term isotopic datasets due to non-existent or inadequate in-country water-isotope capacity. Malawi has made significant advances in its quest to establish a stable isotopic baseline through the establishment of the Malawi Network of Isotope in Precipitation. This study provides the first results for the isotopic characterization of precipitation in Malawi with a view to reinforcing understanding of the country's hydrological cycle. Error-in-variables regression defined a Local Meteoric Water Line as $\delta^{2} \mathrm{H}=8.0( \pm 0.3) \delta^{18} \mathrm{O}+13.0( \pm 2.0)$ using stable isotopic records of 37 monthly samples from 5 stations between 2014 and 2019. Local precipitation (isotopic composition) is consistent with global precipitation expectations, its condensation-forming process occurring under equilibrium conditions and a higher intercept (d-excess) above the 10\% for Global Meteoric Water Line, implying that air moisture recycling significantly influences local precipitation. Wider variations observed in local precipitation isotopic signatures are largely attributed to different moisture-bearing systems and diverse geographic factors across the country. Additional stations are recommended to improve spatial coverage that, together with longer temporal records, may help understanding and resolving uncertainties such as the altitude effect. This pioneering study is expected to facilitate Malawi's ambition to achieve integrated use and improved protection of its surface water and groundwater resources in response to mounting climate change, growing population and land-development concerns.
\end{abstract}

Keywords: precipitation; Stable Isotope Baseline; Local Meteoric Water Line; Integrated Water Resources Management; deuterium excess; Malawi

\section{Introduction}

Integrated Water Resource Management (IWRM) requires an understanding of the provenance of the various water sources contributing to a resource that may enable their protection. Establishing the stable-isotopic signature of these waters and mixed waters subsequently occurring within water resources provides diagnostic insight into the physical processes the water has been subjected to over time, the identification of possible water sources and the improved understanding and conceptualization of the local or regional hydrological cycle; all which underpin IWRM [1-5].

The diagnostic value of surface water and groundwater resource stable-isotope signatures is predicated upon the characterization of isotopic signatures present in meteoric (precipitation) inputs [6-9]. It is important to the national-scale implementation of IWRM that countries establish stable-isotopic baseline signatures in local precipitation. In developing countries such as Malawi and across Sub-Saharan Africa (SSA), baseline development and wider isotopic tool use have been hindered by poor socioeconomic conditions, little 
investment in the science and a lack of in-house isotope analytical facilities. Reliance to date has been on samples collected and exported by researchers in developed countries leading to sporadic isotope studies in Malawi [10-17].

Malawi has a complex land-locked hydrology. The north-south-oriented country spans significant latitude from $9^{\circ} \mathrm{S}$ to $17^{\circ} \mathrm{S}$. Its location at a southern extremity of the East African Rift System (EARS) results in significant topographic variation, from $c .30$ to $3000 \mathrm{~m}$ asl. Lake Malawi covers 23\% of the surface area of the country and its setting within the larger African Great Lakes region (incl. Malawi, Victoria and Tanganyika) results in a predominant great-lake influence (a significant source of moisture) on its East African regional climate [18]. It experiences a sub-tropical climate influenced by altitude, relief and Lake Malawi. It is generally cool in plateau areas but hot in the rift valley, becoming increasingly semi-arid from the north to the southern lowlands. Seasonal contrasts are significant with distinct wet (November-April) and dry (May-October) seasons driven by north-easterly winds (Mpoto) in the former and strong south-easterly winds (Mwera) in the latter seasons. Topographically influenced mean temperatures range from 17 to $37^{\circ} \mathrm{C}$ in the hot-dry season. Precipitation is influenced by the migration of the Inter Tropical Convergence Zone (ITCZ), Congo Air Boundary (CAB) and Tropical Cyclones [19]. Given the above complexities, spatial-seasonal characterization of variations in precipitation stable-isotope signature across Malawi is vital to assess the expected depletion of heavier isotopes from increased latitude, closeness to the continental interior and increased altitude due to temperature variations and 'rainout' effects [18]. To date, Malawi has relied upon stable isotopic data records from Global Network of Isotopes in Precipitation (GNIP) stations located outside the country [10-17]. Malawi represents a gap in SSA's regularly monitored network.

The country is vulnerable to several 'global issues'. Although there are substantial surface water resources within Lake Malawi and its Shire River outflow, these only provide pipeline supplies to its urban centers. Most of Malawi's population is the rural poor, in common with around half a billion people in SSA [20], almost exclusively reliant on groundwater [21]. Such supplies are affected by functionality concerns, a global issue, with many of Malawi's circa 120,000 water points vulnerable to 'asset stranding', driving the consideration of IWRM alternatives [22,23]. Malawi's water resources are also vulnerable to a host of development pressures, including irrigated agriculture, urbanization, rapidly increasing population (c. 3\% annually), increasing (hydroelectric) energy needs and deforestation; each disturbing hydrological systems and disrupting the sensitive balances between runoff and recharge [24-29]. Malawi has a significant vulnerability to climate change and associated intensification of drought and flood events. Although influence is already probable, evidenced by a series of climatic perturbations in SSA [30-32] and in Malawi [30,33-35], the priority remains to establish current baselines (including stable isotopes) to benchmark further change. Finally, as a landlocked country neighboring Mozambique, Tanzania and Zambia, and its main Shire River draining into the Zambezi River also influencing Angola, Botswana, Namibia and Zimbabwe, Malawi has significant transboundary aquifer and surface water obligations [36].

Malawi is one of the world's most physically vulnerable places to repercussions resulting from climate change $[37,38]$. The country has recorded climatic evidence of significant temperature variability and increased intensity and frequency of occurrence of floods and drought [29-35]. Climate-change-induced perturbations in the Sub-Saharan precipitation regime causing a rise in numerous severe weather incidents are also asserted [30-32].

Our research is an outcome of the partnership between the International Atomic Energy Agency (IAEA) and Malawi's Ministry of Forestry and Natural Resources that enabled the 2018 commissioning of an isotope hydrology national facility. This specifically comprises the operationalization of an Isotope Hydrology Laboratory (IHL) and the establishment of the Malawi Network of Isotopes in Precipitation (MNIP). The data collected to date from the MNIP form our focus herein. The objectives set were to establish a stable isotopic baseline for precipitation at national scale for Malawi, to understand the factors 
that may influence spatial and temporal (intra-seasonal) isotopic signature variability and to develop a Local Meteoric Water Line (LMWL) for Malawi that will act as a benchmark for future isotopic studies assessing water-resource status. The overarching goal was to provide a foundational characterization of precipitation that will reinforce understanding of Malawi's hydrological cycle and thereby underpin future IWRM and policy decision making. This study represents the first-ever characterization of the stable isotope precipitation baseline for Malawi and hence provides a pivotal step to achieving the long-held ambition to provide isotope-informed IWRM for the country. Study findings have already helped underpin our companion catchment [39] and basin-scale [40], stable-isotope studies in Malawi and ongoing studies of other catchments.

\section{Materials and Methods}

\subsection{Study Area Setting}

Malawi occurs as an elongate plateau towards the south-western extreme of the lower EARS that structurally dominates its landform (Figure 1). Its diverse physiography ranges from highlands reaching $3000 \mathrm{~m}$ asl, plateau occurring at 750-1300 m covering much of the country, rift valley scarp and the rift valley and associated plains that decline to around 30-100 $\mathrm{m}$ asl in the Lower Shire Valley-Mozambique border. The highland and plateau comprise normal-faulted blocks of Precambrian and Lower Palaeozoic Basement gneiss and granulite rock (the pan-African 'basement rock') with Quaternary colluvium, alluvium and lacustrine basins forming the rift valley plains. These form Malawi's three main aquifer types; the weathered basement rock, the often-underlying fractured basement rock and the valley alluvial aquifer systems upon which rural Malawians extensively rely upon for water supply $[21,22,41]$.
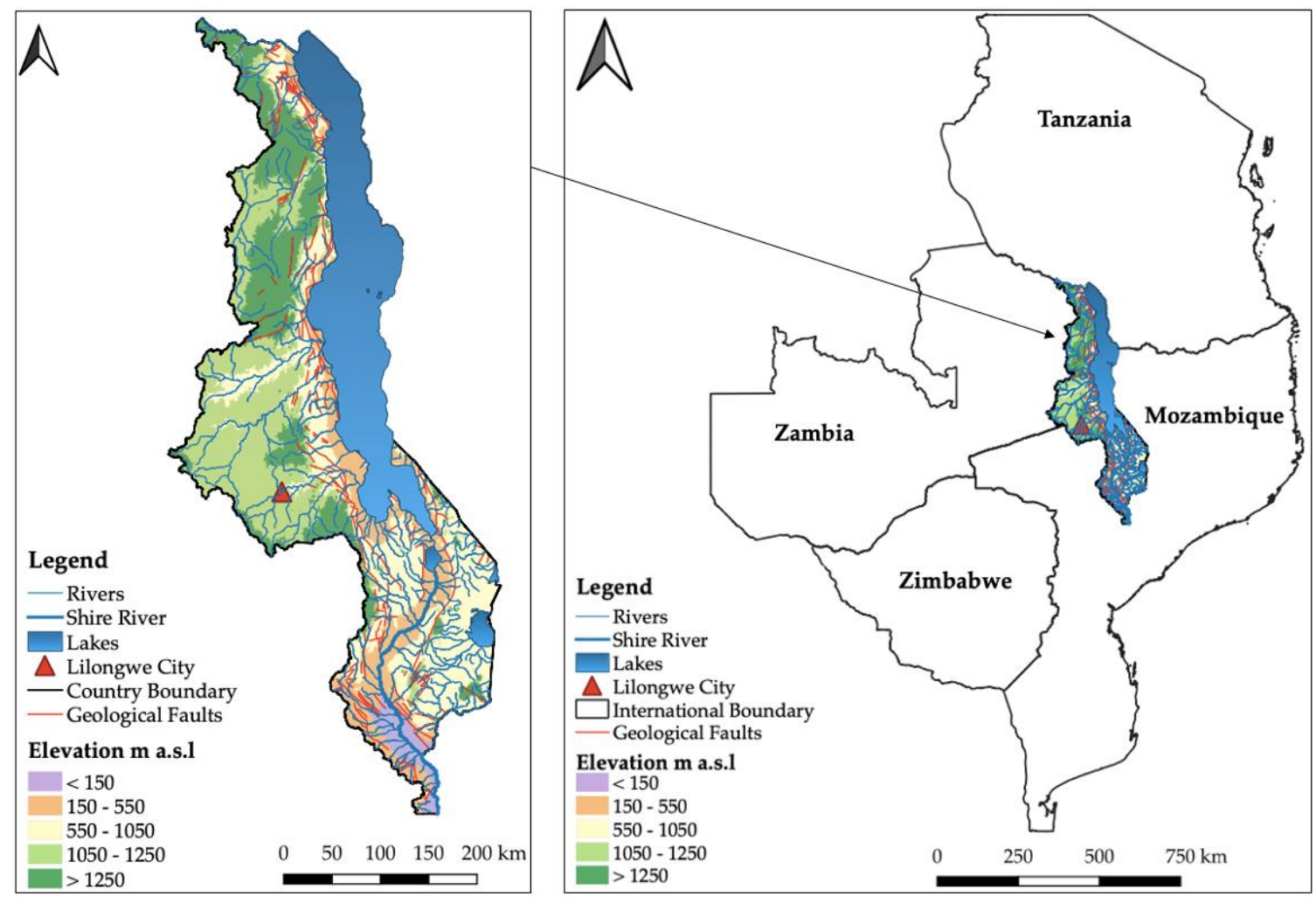

Figure 1. Study area showing topography (various colored zones), major rivers, lakes, fault lines and neighboring coun-tries.

Malawi's drainage system is dominated by the Lake Malawi-Shire River system, into which a vast network of many of its rivers drain (e.g., Ruo, Linthipe, Rukuru and Dwangwa). A few rivers drain to the endorheic Lake Chilwa basin to the east of the rift valley. Other moderately large lakes (Chiuta and Malombe) also exist, as well as many 
dams (reservoirs) constructed for water supply. Malawi is a water-stressed nation, and in particular, groundwater and surface water resources during the dry season are significantly stressed, especially in severe drought years [21].

\section{Climate and Precipitation Derivation in Malawi}

Malawi's climate is sub-tropical, with generally cool conditions experienced in the plateau and hot, dry conditions in the rift valley. A distinct wet season from November to April and dry season from May to October occurs throughout the country. Based on the revised Köppen-Geiger system, Malawi's climate may be classified as Aw or Savannah, with the following defining criteria; 'Not (Af) and Pdry $<100-\mathrm{MAP} / 25$ ', where Af is rainforest, MAP is mean annual precipitation and Pdry is precipitation of the driest month [35]. ITCZ migration southwards between December and January, and northwards between February and March, accounts for the moisture for most of Malawi's precipitation. South-east trade winds blowing across the Indian Ocean from east to west along the Mozambique Channel occasionally bring widespread heavy precipitation in April extending into May in northern Malawi, and infrequent tropical storms that vary in impact and intensity. Due to its proximity to the East African Coast, Malawi experiences rather light precipitation and drizzles (locally known as Chiperoni) mainly during early month of July, particularly in highlands facing south-east [29].

Malawi's precipitation regime has two distinct features: a region with a strong precipitation maximum in austral autumn along Lake Malawi's western shoreline and a brief period of reduced precipitation in mid-February ascribed to a shift in prevailing precipitation and circulation regime [42]. The precipitation regime is characterized by strong seasonality, inter-annual fluctuations and intra-annual spatial and temporal distribution and variability, which are critical to water resources planning and management [43]. Interannual monthly precipitation is influenced by Indian Ocean Sea Surface Temperature (SST) attributed to the El Niño Southern Oscillation Phenomenon [43]. Annual precipitation ranges from $725 \mathrm{~mm}$ to $2500 \mathrm{~mm}$ and the country's precipitation is largely influenced by diverse topography and proximity to Lake Malawi $[44,45]$. Generally, highlands receive the highest and lowlands the lowest precipitation amount. Most of the precipitation (c. 90\%) occurs between November and April [46]. Within this period, precipitation is concentrated between December and March, with maxima occurring in January in most of the country but delayed until March, close to Lake Malawi's western shoreline [42].

\subsection{Malawi Network of Isotopes in Precipitation (MNIP): Design, Sampling and Analysis}

The Government of Malawi, with funding from International Atomic Energy Agency (IAEA) established a monitoring network of isotopes in precipitation at national scale through the Water Resources Department (WRD) in the Ministry of Forestry and Natural Resources between 2014 and 2018. The monitoring network is known as the 'Malawi Network of Isotopes in Precipitation' (MNIP), and Figure 2a locates the MNIP stations. The MNIP was commissioned for collection of systematic data on isotopic signatures of precipitation for the establishment of a stable isotopic baseline for precipitation at national scale. Currently, it comprises five (5) stations (sited at (3) and near (2) meteorological service stations) equipped with a rain collector 'dip-in sampler' and access to meteorological equipment for measuring meteorological parameters (e.g., rain gauge for measuring precipitation amount). The siting rationale of the MNIP stations aimed at providing balanced national coverage and capturing influences of different weather systems affecting precipitation across the country. This was a fledgling starter network meant to be expanded (by geostatistical tools to achieve an optimal network design) with additional stations for spatial and temporal enhancement of the isotopic data records [47].

Between 2014 and 2019, a total of 40 monthly water stable-isotope samples were collected from the MNIP stations (Table 1) using dip-in samplers designed to prevent evaporation (and eliminate the need for paraffin) [48]. The water stable-isotope samples were collected on a daily and a weekly basis and thereafter mixed to provide integrated 
monthly samples. Samples were contained in $25 \mathrm{~mL}$ brown (light-proof) bottles with airtight caps and no headspace and kept at $4{ }^{\circ} \mathrm{C}$ during transportation and holding. Laboratory analysis involved daily, weekly and monthly precipitation samples, with monthly samples being the focus of this study. A sub-dataset $(n=37)$ (from stations with precipitation amount data) generated from monthly precipitation amount weighted samples were then used to derive a national Local Meteoric Water Line (LMWL) using error-in-variables regression analysis denoted EIV-LMWLw. The EIV-LMWLw equation included standard errors (representing mean deviation of isotopic values from the EIV-LMWLw) for its slope and intercept [39,49]. The weighted EIV-LMWLw equation was then compared with a nonEIV-LMWLw equation derived from a regressed entire non-weighted dataset $(n=40)$ to check any variations in extent of slope and intercept that were found to be insignificant. Summary statistics of precipitation isotopic data were computed based on the entire dataset (weighted and non-weighted), but the LMWL and other isotope-related graphs focused only on the precipitation amounts weighted dataset.

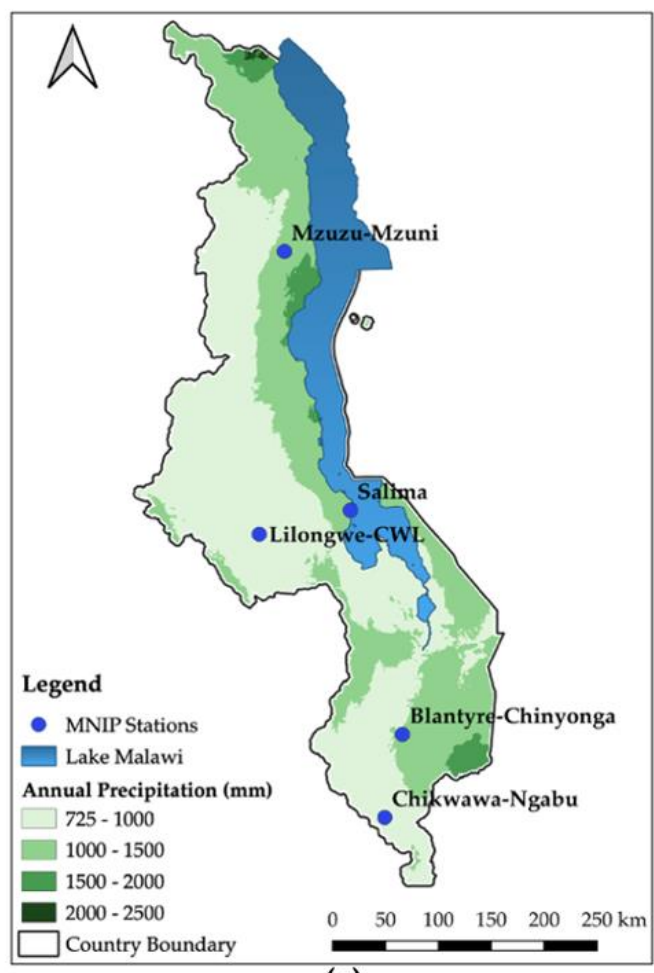

(a)

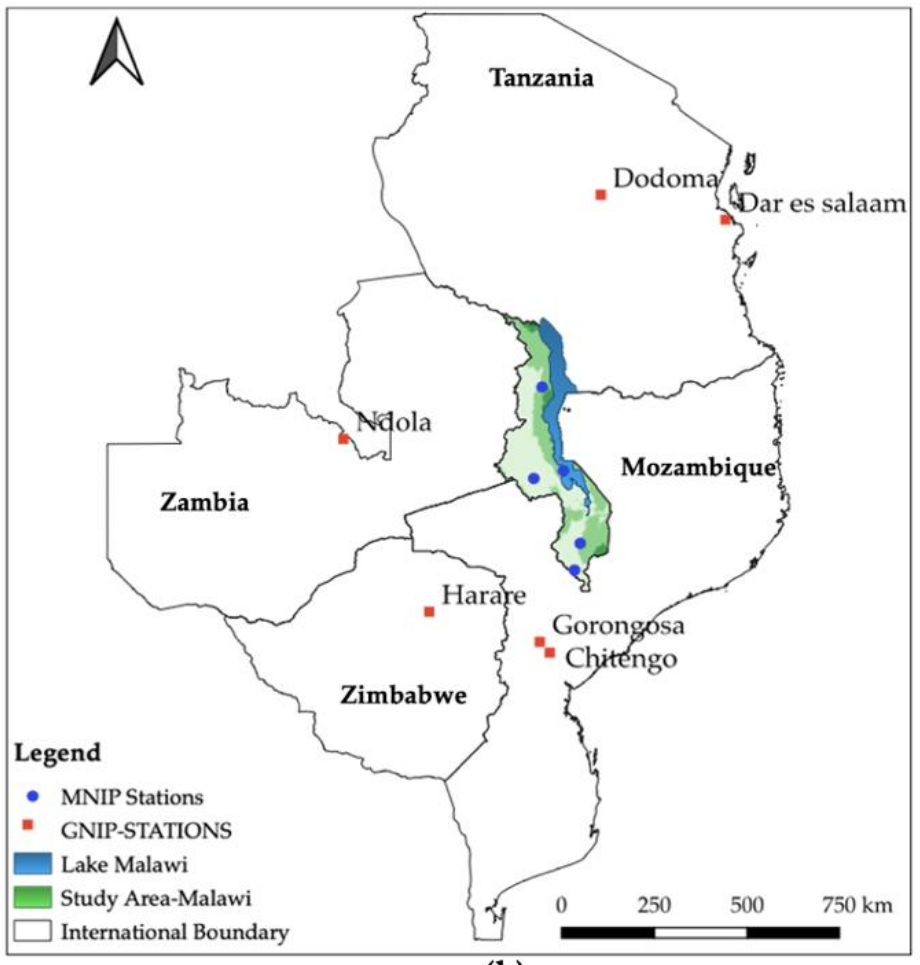

(b)

Figure 2. Malawi-network of isotopes in precipitation (MNIP) stations (a) and global network of isotopes in precipitation (GNIP) stations (b).

Analysis of oxygen $\left({ }^{18} \mathrm{O} /{ }^{16} \mathrm{O}\right)$ and deuterium $\left({ }^{2} \mathrm{H} /{ }^{1} \mathrm{H}\right)$ ratios was undertaken using an automated cavity ring-down spectrometer, specifically a Picarro isotopic water analyzer (Model: L2110-I, Picarro, Santa Clara, CA, USA) at Ministry of Forestry and Natural Resources Isotope Hydrology Laboratory (IHL). Daily calibration of light and heavy standards encompassing the expected ranges of isotopic signatures in the samples was undertaken, alongside the use of a daily control mid-range intermediate standard. The Picarro isotopic water analyzer was prepared by running two vials of deionized water, and accuracy of measurement was checked by inspecting concentration peaks, with adherence to an acceptable range of 19,000-21,000 ppm for abundance of isotope ratios for both deuterium $\left(\delta^{2} \mathrm{H}\right)$ and oxygen-18 $\left(\delta^{18} \mathrm{O}\right)$. The isotopic analysis precision $(2 \sigma)$ was set at $\pm 0.2 \%$ for oxygen- 18 and $\pm 2.0 \%$ for deuterium, while quantification and validation of results were accomplished via dedicated Laboratory Information Management System (LIMS) software. The processed isotopic analysis results were reported in delta values $\left(\delta^{2} \mathrm{H}\right.$ and $\left.\delta^{18} \mathrm{O}\right)$ representing parts 
per thousand (\%) deviations from the international Vienna-Standard Meteoric Ocean Water (V-SMOW) $[50,51]$ with precision $(2 \sigma)$ of \pm 0.2 permil for $\delta^{18} \mathrm{O}$ and \pm 2.0 permil for $\delta^{2} \mathrm{H}$. The deuterium excess parameter was calculated from Dansgaard's equation relating $\delta^{18} \mathrm{O}$ and $\delta^{2} \mathrm{H}$ of water, defined as $\mathrm{d}=\delta^{2} \mathrm{H}-8 \delta^{18} \mathrm{O}$ [52]. The water stable-isotope chain-of-custody (onsite measurements, sample collection, transportation, holding, preparation and analysis) adhered to International Standard Methods [53].

Table 1. Summary of isotopic sampling undertaken from Malawi Network of Iso-topes in Precipitation (MNIP) Stations (1914-2019).

\begin{tabular}{|c|c|c|c|c|c|}
\hline \multirow{2}{*}{$\begin{array}{l}\text { Meteorological } \\
\text { Services Stations }\end{array}$} & \multirow{2}{*}{$\begin{array}{l}\text { MNIP } \\
\text { Stations }\end{array}$} & \multicolumn{2}{|c|}{ Decimal Degrees } & \multirow{2}{*}{$\begin{array}{r}\text { Altitude } \\
\text { (m a.s.l) }\end{array}$} & \multirow{2}{*}{ Monthly Samples } \\
\hline & & Latitude & Longitude & & \\
\hline Mzuni & Mzuni & -11.41977 & 33.9952843 & 1287 & 6 \\
\hline Chitedze & Chitedze & -13.976628 & 33.7686897 & 1046 & 18 \\
\hline Salima & Salima & -13.75 & 34.5892292 & 512 & 4 \\
\hline Ngabu & Ngabu & -16.536863 & 34.8912164 & 80 & 7 \\
\hline Chichiri & Chinyonga & -15.813924 & 35.0397645 & 1127 & 5 \\
\hline
\end{tabular}

* Meteorological services stations associated with MNIP stations; CWL: Central Water Laboratory.

The study focused on the only available stable isotopic data generated during wet season as Malawi's precipitation is largely received during this time of the year. Hence, only intra-seasonal variability of isotopic signatures of local precipitation was investigated, not inter-seasonal variability. Thus, the intra-seasonal variability in stable isotopic signatures of local precipitation has been displayed in Supplementary Material (SM) Figure S1 by way of averaging weighted monthly isotopic values of precipitation for each month of the wet season over the period 2014-2019. The upcoming phase of our work will largely focus on generating seasonal isotopic data for investigating inter-seasonal variability in isotopic signatures of local precipitation.

The local precipitation data were augmented by precipitation isotopic data obtained from neighboring international Global Network of Isotopes in Precipitation (GNIP) stations in Mozambique at Gorongosa (8 monthly samples) and Chitengo (4 monthly samples), Zambia at Ndola (154 monthly samples), Zimbabwe in Harare (188 monthly samples) and in Tanzania in Dar es Salaam (117 monthly samples) to reinforce the national meteoric water characterization and to capture regional status of isotopic signatures (spatially and temporally) thereby allowing a more complete regional meteoric characterization [48] (Figure 2b; Table 2). It was deemed vital to have this surrounding boundary defined for a landlocked country (and expected as standard to do so). The MNIP is spatially lacking and needs infilling, and the temporal earlier isotopic data records are useful to provide some way of extrapolating time series. Above all, the MNIP was designed to fit into the wider international network contribution. The resultant Regional Meteoric Water Line (RMWL) derived from a sub-dataset of precipitation amounts weighted stable isotopic samples $(n=449)$ (from stations with precipitation amount data) from MNIP, and the surrounding GNIP stations were also calculated by error-in-variables regression, denoted EIV-RMWLw.

Table 2. Summary of isotopic sampling undertaken from Global Network of Isotopes in Precipitation (GNIP) Stations (1969-2019).

\begin{tabular}{|c|c|c|c|c|c|c|}
\hline \multirow{2}{*}{$\begin{array}{c}\text { GNIP } \\
\text { Stations }\end{array}$} & \multirow{2}{*}{ WMO Codes } & \multirow{2}{*}{ Country } & \multicolumn{2}{|c|}{ Decimal Degrees } & \multirow{2}{*}{$\begin{array}{r}\text { Altitude } \\
\text { (m a.s.l) }\end{array}$} & \multirow{2}{*}{$\begin{array}{l}\text { Monthly } \\
\text { Samples }\end{array}$} \\
\hline & & & Latitude & Longitude & & \\
\hline Harare & 6777400 & Zimbabwe & -17.83 & 31.02 & 417 & 188 \\
\hline Dodoma & 6386200 & Tanzania & -16.1852 & 35.7533 & 1157 & 18 \\
\hline Dar es salaam & 6389400 & Tanzania & -6.88 & 39.2 & 55 & 117 \\
\hline Ndola & 6756100 & Zambia & -13 & 28.65 & 1331 & 154 \\
\hline Chitengo & 6729501 & Mozambique & -18.9751 & 34.34842 & 34 & 4 \\
\hline Gorongosa & 6729502 & Mozambique & -18.6717 & 34.07239 & 346 & 8 \\
\hline
\end{tabular}




\section{Results and Discussion}

Stable isotopes data obtained from the local (MNIP) and regional (GNIP) precipitation stations have permitted comprehensive characterization of Malawi's current local meteoric system.

\subsection{Co-Isotopic Relationships of Local Precipitation}

Error-in-variables (EIV) regression was applied to the stable isotopic dataset collected from the MNIP stations to calculate a Local Meteoric Water Line (LMWL) that describes Malawi's local meteoric characteristics. The local meteoric water line (EIV-LMWL) is defined as: $\delta^{2} \mathrm{H}=8.0 \pm(0.3) \delta^{18} \mathrm{O}+13.0( \pm 2.0)$ (Figure 3). The EIV-LMWL shows a strong positive correlation between $\delta^{2} \mathrm{H}$ and $\delta^{18} \mathrm{O}$ values of local precipitation of slope consistent with the Global Meteoric Water Line (GMWL), defined as: $\delta^{2} \mathrm{H}=8 \delta^{18} \mathrm{O}+10$ [50]. The stable isotopic signatures of local precipitation from the MNIP stations registered a mean deuterium excess value of $13.3 \%$, slightly above the GMWL intercept of $10 \%$. This is characteristic of local vapor recycling contribution to the local precipitation isotopic signatures [54]. A subset of the MNIP samples that plotted below the GMWL is indicative of the re-evaporation of raindrops during precipitation events (Figure 4) $[55,56]$. Most of the local precipitation samples scattered along the EIV-LMWL, with almost all the samples plotting within the prediction error band. This corroborates that there were insignificant evaporative influences on the local precipitation and were further substantiated by the EIV-LMWL slope $8.0( \pm 0.3)$, which is characteristic of non-evaporated rains.

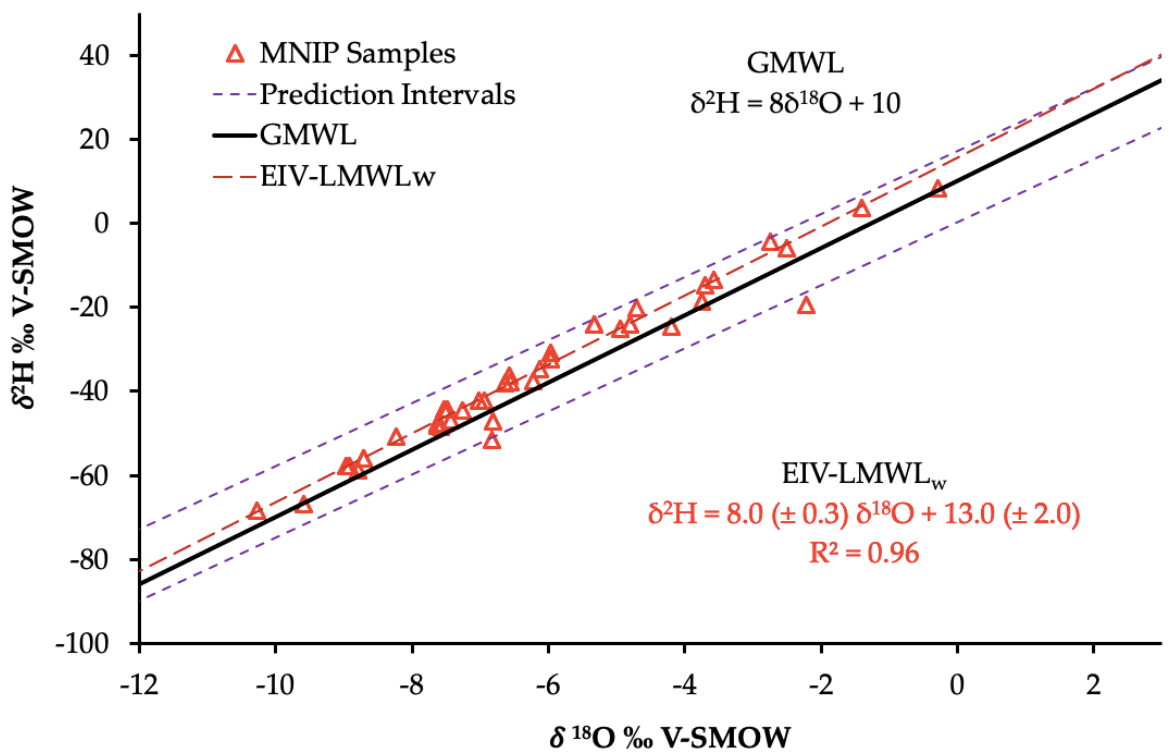

Figure 3. Monthly precipitation stable-isotope data for MNIP stations ( $n=37)$. Error-in-variables local meteoric water line (EIV-LMWLw) represents the weighted local meteoric water line for Malawi (calculated based on error-in-variables regression analysis). MNIP: Malawi network of iso-topes in precipitation; GMWL: Global Meteoric Water Line.

\subsection{Isotopic Signature of Local and Regional Precipitation}

The current MNIP stations' dataset was judged insufficient to meet our goals, and hence, characterization of the local meteoric conditions was augmented by surrounding GNIP stations' datasets. This permitted a more regionally representative LMWL relative to the origin of air masses that was defined as $\delta^{2} \mathrm{H}=7.6 \pm(0.1) \delta^{18} \mathrm{O}+10.0( \pm 0.5)$ (Figure 4). The EIV-LMWL is quite consistent with the regional meteoric water line defined as $\delta^{2} \mathrm{H}=7.6( \pm 0.1) \delta^{18} \mathrm{O}+9.9( \pm 0.5)$ (Figure 4$)$ derived from the surrounding GNIP stations datasets. The slopes of both meteoric water lines are identical but somewhat less than the GMWL slope of 8 . This is ascribed to evaporative influence on the isotopic signatures of 
precipitation events as well as possible isotopic non-equilibrium conditions affecting the rain-out process.

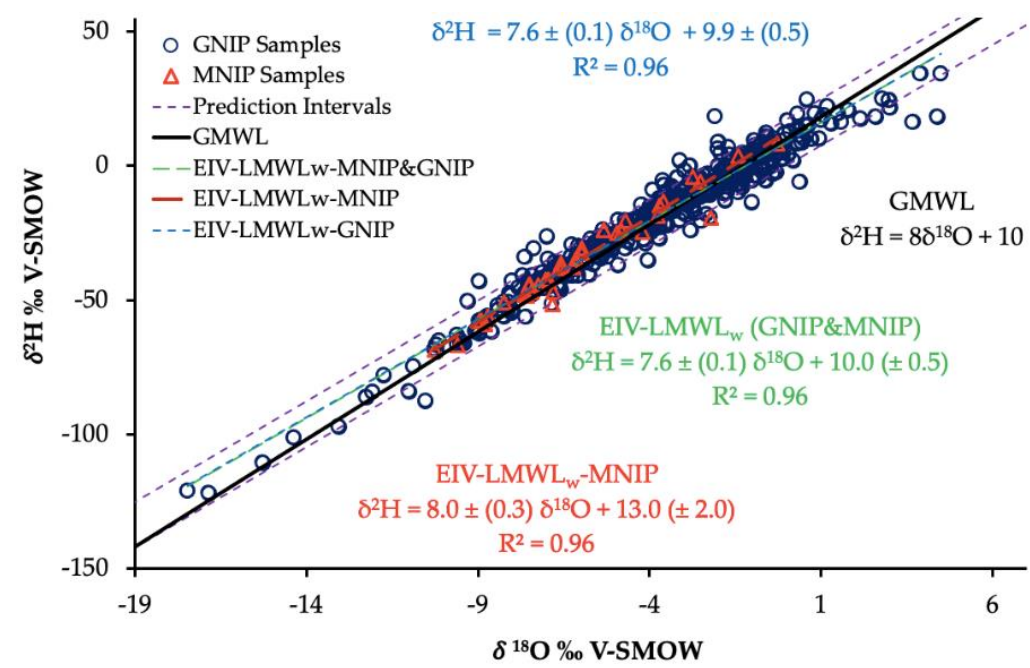

Figure 4. Plot of $\delta^{2} \mathrm{H}$ and $\delta^{18} \mathrm{O}$ for precipitation stable-isotopic samples from MNIP stations $(\mathrm{n}=37)$ and GNIP stations $(\mathrm{n}=409)$. Error-in-variables local meteoric water line (EIV-LMWLw) represents the weighted local meteoric water line calculated based on error-in-variables regression analysis. MNIP: Malawi network of isotopes in precipitation; GMWL: Global Meteoric Water Line.

The scenario reinforces the need for continuity and long-term collection of water stable-isotopic data from the MNIP stations to significantly improve both the EIV-LMWL local representativeness and its significance in contributing to the regional global water stable-isotopic meteoric characterization.

\subsection{Isotopic Signature Variability of Local and Regional Precipitation}

The MNIP stations' monthly dataset displayed wide variations spanning a range of $76.8 \%$ for $\delta^{2} \mathrm{H}$ and $10 \%$ for $\delta^{18} \mathrm{O}$ (Table 3). This is attributed to distinct rain-bearing systems and varying geographic factors resulting from the country's extremely diverse physiographic zones. The wide variation evident in the water stable-isotopic signatures is consistent with the expected water stable-isotopic signatures of Indian Ocean monsoonderived precipitation [57]. The surrounding GNIP stations dataset displayed even wider variation (range: $159 \%$ for $\delta^{2} \mathrm{H} ; 22 \%$ o for $\delta^{18} \mathrm{O}$ ) relative to the MNIP stations dataset (Table 3). This was attributed to spatial and/or intra-seasonal variability among other factors such as temporal and geographic scales. Plotting of the MNIP dataset within the prediction band supports evaporative effects on local precipitation were insignificant (Figure 5). A GNIP stations sub-dataset, however, did plot outside the prediction band, below the GMWL, signaling an oxygen-18 excess. This feature might indicate secondary evaporation of raindrops during the fall and above the GMWL (representing excess deuterium), from which precipitation originated from recycled air moisture is inferred.

\subsection{Intra-Seasonal Isotopic Signature Variability of Local Precipitation}

The stable isotopic signatures of local precipitation varied significantly monthly, with the largest isotopic signatures variation depicted between January and April ascribed to weather systems transitioning (SM-Figure S1). The most depleted isotopic signatures of $\delta^{18} \mathrm{O}$ and $\delta^{2} \mathrm{H}$ were recorded in January, the peak month of the wet season, whereas the most enriched isotopic signatures of $\delta^{18} \mathrm{O}$ were recorded in April, the end of the wet season. The enriched isotopic signatures of $\delta^{18} \mathrm{O}$ and $\delta^{2} \mathrm{H}$ are indicative of drier-warmer conditions during the end of the wet season (SM-Figure S1. Overall, the isotopic compositions of rainfall in Malawi increase as the ITCZ migrates northwards around April. Therefore, there is a need for further investigation at a regional scale coupled with the collection of 
high-resolution isotopic data across various catchments in Malawi to better understand the spatial distribution variation with time across the country.

Table 3. Summary of stable isotopic signatures of precipitation from (a) MNIP stations and surrounding GNIP stations.

\begin{tabular}{cccccccc}
\hline MNIP Stations & & & & & & & \\
\hline Variable & Count & Min. & Max. & Mean & Median & StDev. & Range \\
\hline$\delta^{2} \mathrm{H}$ & 40 & -68.4 & 8.40 & -35.9 & -38.0 & 18.7 & 76.8 \\
$\delta^{18} \mathrm{O}$ & 40 & -10.3 & -0.29 & -6.15 & -6.61 & 2.30 & 9.98 \\
D-excess & 40 & -1.64 & 18.6 & 13.3 & 13.9 & 3.80 & 20.3 \\
\hline GNIP Stations & & & & & & & \\
\hline$\delta^{2} \mathrm{H}$ & 489 & -122.1 & 36.4 & -20.6 & -17.7 & 23.9 & 158.5 \\
$\delta^{18} \mathrm{O}$ & 489 & 17.5 & 4.5 & -4.0 & -3.7 & 3.2 & 22 \\
D-excess & 489 & 17.3 & 34.6 & 11.2 & 12 & 5.48 & 51.8 \\
\hline
\end{tabular}
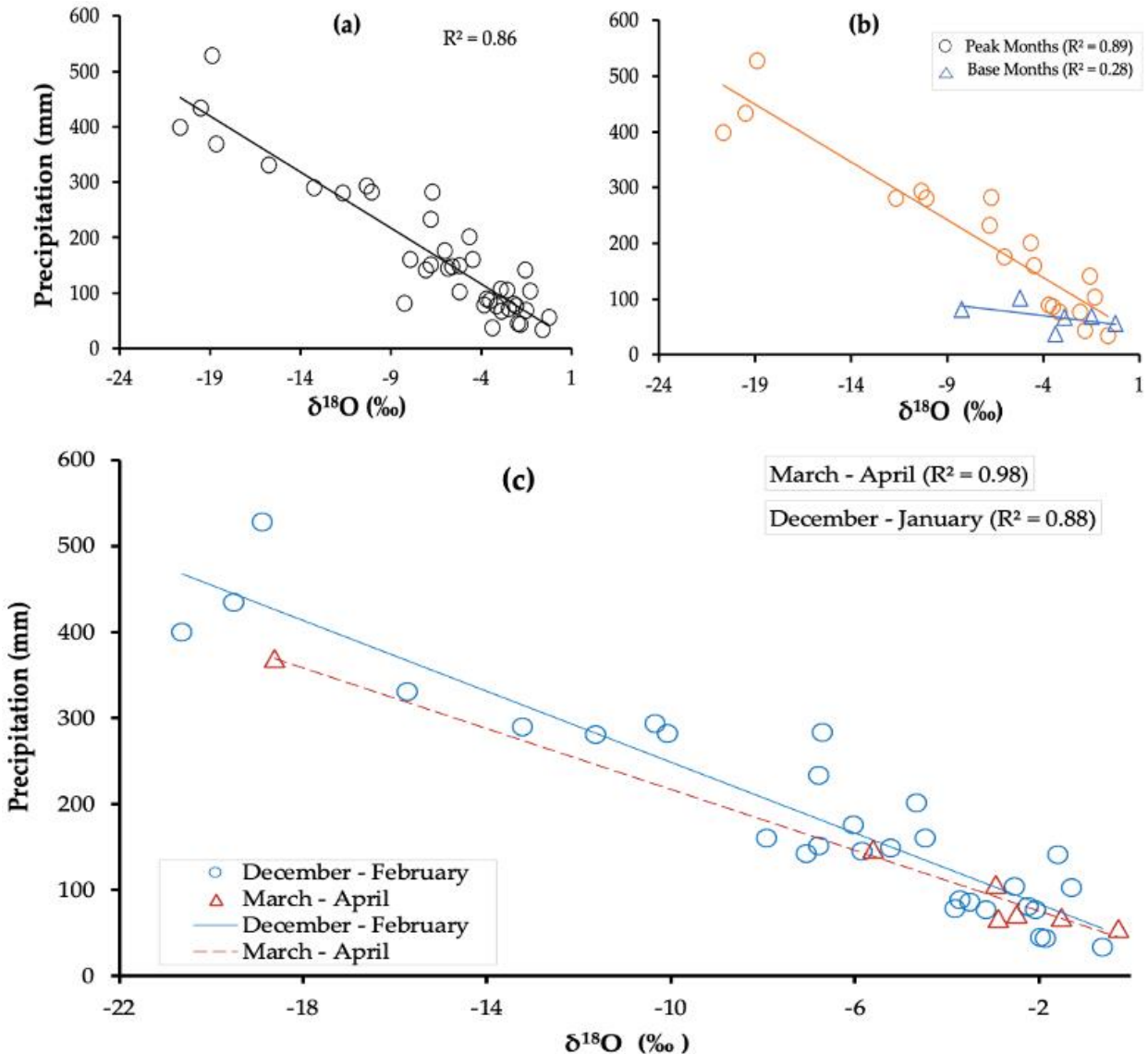

Figure 5. Precipitation amounts plotted versus $\delta^{18} \mathrm{O}$ values for (a) all monthly data and (b) the intraseasonal relationship for MNIP stations for peak and base months over the period 2014-2019. (c) the intra-seasonal relationship for MNIP sta-tions for early (December-February) and late (March-April) phases of the wet season over the period 2014-2019.

\subsection{Isotopic Signature and Precipitation Amount Relationship: 'Amount Effect'}

A strong correlation $\left(\mathrm{R}^{2}=0.86\right)$ was observed between precipitation amount and stable isotopic signatures of local precipitation at the monthly scale (Figure 5a). An increasing trend in precipitation amounts corresponded to highly depleted isotopic signatures. The 'amount effect' is generally influenced by actual precipitation amount with precipitation intensity dominating [52]. Thus, several precipitation events of lesser intensity, with a 
cumulative higher amount, can result in less depleted isotopic signatures, and contrasts with a few precipitation events of higher intensity, with a cumulative low amount, that can exhibit highly depleted isotopic signatures [2]. Peak months of the wet season (DecemberJanuary) study depicted a stronger relationship $\left(\mathrm{R}^{2}=0.89\right)$, suggestive of precipitation derived considerably more from convective events. This contrasts with the onset and end of wet season months (base months) (November and April, respectively) having a weaker relationship $\left(\mathrm{R}^{2}=0.28\right)$, ascribed to precipitation episodes under the influence of frontal origins (Figure 5a), as echoed by Darling (2003) [2].

The precipitation 'amount-effect' was also investigated considering the dual nature of Malawi's wet season, which, after the early phase (December-February), has a slight break or lull in precipitation, followed by the late phase (March-April). Precipitation during these phases is derived from contrasting atmospheric circulation regimes [42]. During these phases, the stable isotopic signatures of local precipitation are strongly influenced by precipitation amounts (Figure 5c). The 'amount effect' varied considerably at higher precipitation amounts as compared to low precipitation amounts between the early and late phases. Overall, the current dataset has not depicted clear dependencies of the isotopic signatures on altitude or temperature but rather the influence of the ITCZ as it migrates southward and northward in Malawi. Considering the present data records limitation, especially for the late phase, it will be extremely interesting to further investigate the nature of the isotopic relationships that exists in local precipitation using more robust temporal and spatial isotopic data records.

\subsection{Isotopic Signature and Altitude/Temperature Relationships}

An observed altitude effect is indicative of a temperature effect attributed to cooling air masses with increasing elevation. This has largely been reported to be insignificant in lowlands and significant in uplands/highlands [58,59]. Altitude effects were investigated during the months of December and January for the period 2014-2019 (SM-Figure S2). These are the months with good records for all the five stations. The rest of the months have significant data gaps and do not warrant investigation. Moderately correlated relationships between altitude and $\delta^{18} \mathrm{O}$ signatures were observed for December and January precipitation events, but weak correlations for February (SM-Figure S2). In both instances, precipitation tended to be isotopically depleted with increasing altitude. A poor correlation of isotopic signatures $\left(\delta^{18} \mathrm{O}\right)$ with altitude was found and most likely ascribed to the geographical separation of the precipitation stations (Malawi being a long stretch of land from north to south, with contrasting topographic settings) and varying sources of air moisture. The precipitation stations in southern Malawi are predominantly influenced by Indian Ocean air Masses and El Niño, while other stations in northern Malawi are mainly influenced by the ITCZ. Thus, it could be that this lack of climatic relationship between some of the stations may potentially render it impossible to conclude a national altitude effect for Malawi at this stage, but local scale data collection is advised for future study.

A poor correlation between isotopic signatures $\left(\delta^{18} \mathrm{O}\right)$ and temperatures was also observed and attributed to the extreme geographical separation among the precipitation stations as observed for the altitude effect (SM-Figure S3). The other factors attributing to such poor correlation could be the varying air moisture sources influencing rainfall at the stations. Additionally, intense secondary evaporation effects in southern Malawi compared to elsewhere in the country alongside re-evaporation influence may be significant contributing factors to isotopic variation with respect to temperature.

\subsection{Deuterium Excess Variability and Frequency Distribution}

The monthly variation of deuterium excess in precipitation over the period 2014-2019 shows that the highest deuterium excess values were recorded during the month of January, while the lowest deuterium excess values were recorded during February. The deuterium excess values are greater than $10 \%$ for GMWL, indicating that there is a considerable con- 
tribution of air masses that generate precipitation by recycling of continental air moisture (SM-Figure S4).

The frequency distribution of deuterium excess of the fledgling MNIP network $(n=40)$ is compared to the surrounding GNIP station record $(n=489)$. The mean and standard deviation calculated from data of the MNIP stations (13.3\%, standard deviation: 3.80$)$ compare to the ones (11.2\%o, standard deviation: 5.48 ) calculated from the GNIP stations. (Figure 6a). Observation of the MNIP peak at 13-15\% is important in assessing the provenance of air masses. The frequency distribution of deuterium excess supports that precipitation from the MNIP station is influenced by recycled continental moisture of the atmospheric reservoir. Most deuterium excess values (87.5\%) fell within the range of $10-20 \%$ o that are characteristic of wet season rains which are typical of and expected for MNIP stations due to the high wet season precipitation proportion. A few deuterium excess values $(12.5 \%)$ occur within the range of 2-10 and are characteristic of dry-season rains. The surrounding GNIP record (Figure $6 \mathrm{~b}$ ) exhibits a contrasting isotopic fingerprint characteristic of both wet season and dry season rains, more characteristic of the surrounding country localities (shown by precipitation analysis of the GNIP station locations). This is consistent with the slight difference in the characteristics of the LMWL and the regional meteoric water line derived from surrounding GNIP stations datasets. These differences may also provide insight and investigation opportunities into the varying origin of air masses contributing to the seasonal precipitation events at the surrounding GNIP stations (considered beyond our scope herein). The growing dataset from the MNIP stations in future years will test our initial interpretation that appears consistent with the physical expectations. Additional MNIP stations and long-term isotopic data records are required to achieve both spatial resolution enhancement and temporal records increase. Up-scaling of the MNIP will be informed by a detailed geostatistical evaluation of optimal location for additional MNIP stations [47].
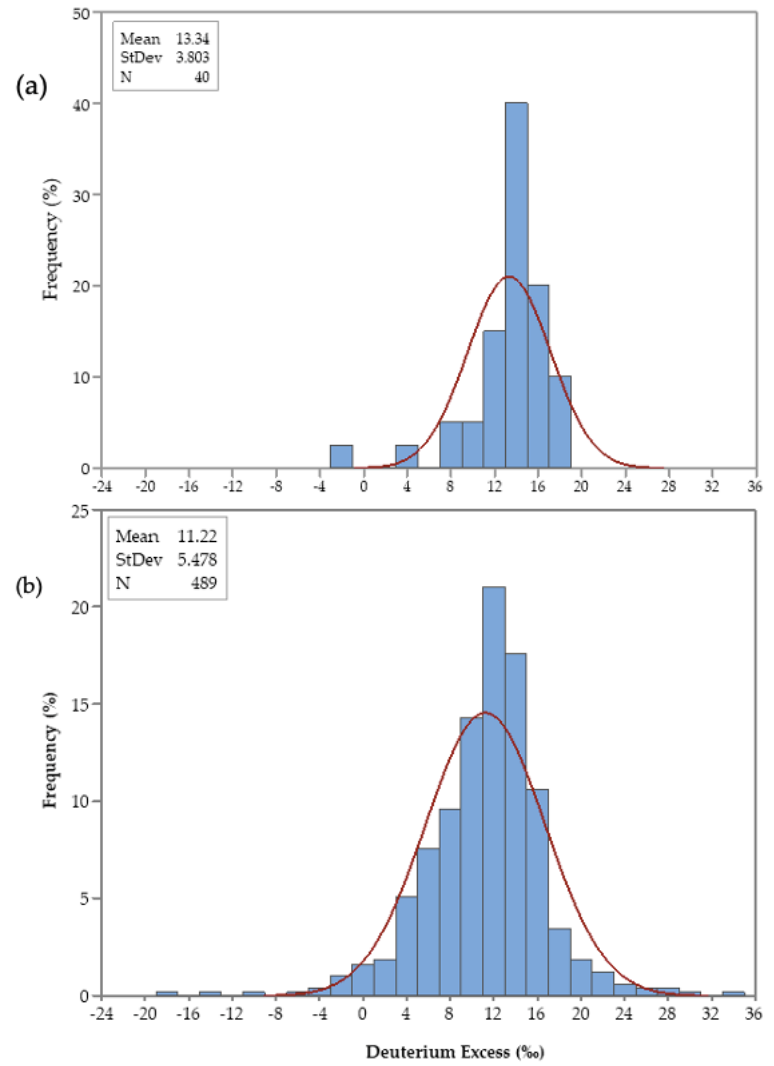

Figure 6. Frequency distribution of deuterium excess signatures for monthly precipitation from (a) MNIP stations over 2014-2019 and (b) surrounding GNIP stations for the period 1960-2016. 


\section{Relationship with Precipitation Moisture Sources}

Malawi's Local Meteoric Water Line (EIV-LMWL $\left.\mathrm{L}_{W}\right)$ generated $\delta^{2} \mathrm{H}=8.0( \pm 0.3) \delta^{18} \mathrm{O}+$ $13.0( \pm 2.0) \%$; confirmed the country's local precipitation was generally consistent with global precipitation expectations, but with the EIV-LMWL $\mathrm{L}_{W}$ displaying a slight shift above the GMWL, suggesting kinetic fractionation during evaporation [60,61]. The LMWL's intercept $(13.0( \pm 2.0) \%$ o representing the deuterium excess value, greater than the GMWL intercept of $10 \%$, is probably due to the influence of the Salima and Central Water Laboratory station samples in Central Malawi and Chinyonga station samples in southern Malawi which recorded higher d-excess values. The LMWL's slope of $8.0( \pm 0.3)$ is comparable with 8.0 for the GMWL, from which it is reasonably inferred that a condensation process leading to local precipitation formation occurred under equilibrium conditions and without significant evaporation phenomena [18,62].

The stable isotopic signatures recorded in local precipitation were clearly distinct and varied widely, suggesting differences in water vapor sources and varying weather systems [61]. This is reasonably ascribed to the country's different precipitation-bearing systems, i.e., the Inter Tropical Convergence Zone (ITCZ), Congo Air Boundary (CAB) and Tropical Cyclones, alongside the influence of geographic controls upon local precipitation variation. This calls for further investigation on how these weather-bearing systems link to the varying water vapor sources. The stable isotopic input signatures of local precipitation were found to be less seasonal than those recorded at the surrounding GNIP stations. This was attributed to the fact that the available dataset largely covered one season (wet season), a period when the country mostly receives rains (wet season rains). As a result, the seasonal variation in the stable isotopic signatures of local precipitation has not been fully investigated at this stage. Going forward, deliberate efforts will be made to fully capture isotopic signatures of dry season rains to provide meaningful resolution of seasonal variability. The altitude effect was investigated, considering significant isotopic variations in local precipitation. However, based on the available isotopic dataset, evidence of the influence of the altitude effect was rather erratic and contrary to conventional trends. Consequently, there is a need for further investigation requiring enhancement of the MNIP temporal and spatial isotopic data records to provide high resolution of the altitude effect. This can be achieved through continuous generation of isotopic data and expansion of the MNIP station from the existing five (5) to at least ten (10) stations. There is also a need for investigation on how daily/weekly precipitation $\delta^{18} \mathrm{O}$ signatures relate to air mass characteristics that contribute to the formation of the local precipitation across the country.

The study findings will largely contribute to the operational component of the MNIP, which was established to collect systematic data on isotopic signatures of precipitation on a national scale, and to establish temporal and spatial variations of environmental isotopes in precipitation. The study provides important foundational isotopic data that will underpin the use of environmental isotopes in hydrological investigations within the scope of water resources management and development.

\section{Conclusions}

The study successfully established a national-scale deuterium and oxygen-18 stableisotope baseline for precipitation in Malawi. This is a first for this developing country and was achieved through the sampling of the recently commissioned Malawi Network of Isotopes in Precipitation (MNIP) and isotope analysis at its own recently established national laboratory facility, removing previous hindrances of sample export abroad for analysis. The Local Meteoric Water Line (LMWL) developed is proposed as a reference benchmark for future and more focused hydrological and climatic studies. The study demonstrates the stable isotope composition of local precipitation was consistent with global precipitation expectations; its condensation-forming process occurring under equilibrium conditions evidenced by a slope of $8.0( \pm 0.3)$ quite comparable to a slope of 8.0 for the Global Meteoric Water Line (GMWL). The precipitation-forming process was also closely associated with atmospheric vapor recycling across the region, the LMWL and 
GMWL slopes being consistent. Variation in stable isotopic signatures of precipitation was attributed to differences in atmospheric vapor sources arising from Malawi experiencing diverse precipitation-bearing systems and distinct geographic-topographic controls within its Rift Valley setting.

The established LMWL will enhance understanding of the hydrological-hydrogeological cycle in Malawi. It is pivotal to providing increased insight into the provenance of meteoric waters, especially of groundwater recharge sources, but also the confirmation of seasonally variant dependency of surface water flows on runoff, baseflow and evaporation losses. The latter process may also impact near-surface groundwater resources, especially in Malawi's semi-arid lowlands. The use of isotopic tools underpinned by the isotopic precipitation characterization herein is already beginning to provide insight into such processes, as demonstrated in our recent basin- [39] and catchment-scale studies [40].

The characterized precipitation isotopic baseline principally contributes to the newly established national stable isotopic database. Looking forward, this is expected to provide a critical underpinning of IWRM implementation in Malawi due to the resolving power of stable-isotope signatures providing forensic insight into the key challenge of understanding the mixing and provenance of the various possible water sources. This is expected to greatly facilitate Malawi's ambition to achieve integrated use and improved protection of its surface water and groundwater resources in its response to mounting climate change, growing population and land-development concerns. Finally, the study valuably contributes to the global network of isotopes in precipitation (GNIP) database by the infilling of the data-record gap previously existed in Malawi. This allows increased certainty in regional and global hydrological and climatic modeling study predictions. The current isotopic data record is regarded as foundational, and spatial network expansion and increased temporal records are both required to reach its full potential and IWRM goals.

Supplementary Materials: The following are available online at https: / www.mdpi.com/article / $10.3390 / w 13141927 / s 1$, Figure S1: Plots of weighted monthly mean values of $\delta^{18} \mathrm{O}(\mathrm{a})$ and $\delta^{2} \mathrm{H}(\mathrm{b})$ recorded at MNIP stations between 2014 and 2019, indicating monthly variations in isotopic signatures of local precipitation. Figure S2: Altitude effects on the $\delta^{18} \mathrm{O}$ signatures of local precipitation in MNIP stations for the months of (a) January (b) February and (c) December over the period 2014-2019. Figure S3: Mean temperatures plotted versus $\delta^{18} \mathrm{O}$ values for all monthly data for the MNIP stations over the period 2014-2019. Figure S4: Deuterium excess for each month of the wet season recorded at MNIP stations, indicating monthly variations in precipitation derived from weighted mean monthly values over the period 2014-2019.

Author Contributions: Conceptualization, L.C.B., M.O.R. and R.M.K.; methodology, L.C.B. and M.O.R.; validation, L.C.B. and A.S.K.Z.; formal analysis, L.C.B. and M.O.R.; investigation, L.C.B.; resources, L.C.B. and A.S.K.Z.; data curation, L.C.B. and A.S.K.Z.; writing-original draft preparation, L.C.B. and M.O.R.; writing-review and editing, M.O.R., L.C.B. and R.M.K.; visualization, L.C.B.; supervision, R.M.K. and S.K.; project administration, R.M.K. and S.K.; funding acquisition, S.K., R.M.K. and L.C.B. All authors have read and agreed to the published version of the manuscript.

Funding: We gratefully acknowledge the funding by the International Atomic Energy Agency (IAEA) under the Malawi Technical Cooperation (TC) Projects' grants (MLW/7/001: MLW/7/002/MLW/7/003), awarded to the Government of Malawi (Department of Water Resources in the Ministry of Forestry and Natural Resources). We also acknowledge the financial contribution we received from the Government of Malawi and the Scottish Government Climate Justice Fund-Water Futures Programme research grant HN-CJF-03 (R. Kalin) awarded to the University of Strathclyde.

Institutional Review Board Statement: Not applicable.

Informed Consent Statement: Not applicable.

Data Availability Statement: The data presented in this study are available on request from the corresponding author.

Acknowledgments: We acknowledge the administrative support by the CJF through BASEflow Malawi.

Conflicts of Interest: The authors declare no conflict of interest. 


\section{References}

1. Barbieri, M. Isotopes in Hydrology and Hydrogeology. Water 2019, 11, 291. [CrossRef]

2. Darling, W.G.; Talbot, J.C.; Darling, W.G.; Talbot, J.C. The O and H stable isotope composition of freshwaters in the British Isles. Rainfall. Hydrol. Earth Syst. Sci. 2003, 7, 163-181. [CrossRef]

3. Gat, J.R.; Shemesh, A.; Tziperman, E.; Hecht, A.; Georgopoulos, D.; Basturk, O. The stable isotope composition of waters of the eastern Mediterranean Sea. J. Geophys. Res. Space Phys. 1996, 101, 6441-6451. [CrossRef]

4. Kalin, R.M. Basic concepts and formulations for isotope-geochemical process investigations, procedures, and methodologies of geochemical modelling of groundwater systems. In Manual on Mathematical Models in Isotope Hydrology; Yurtsever, Y., Ed.; IAEA: Vienna, Austria, 1995; Volume 910, p. 155. Available online: http://www-naweb.iaea.org/napc/ih/documents/TECDOCS/ TECDOC\%200910\%20Mathematical\%models\%201996.PDF (accessed on 8 February 2021).

5. Kalin, R.M.; Long, A. Application of hydrogeochemical modelling for validation of hydrologic flow modelling in the Tucson Basin Aquifer, Arizona, USA. In Mathematical Models and Their Applications to Isotope Studies in Groundwater Hydrology; IAEA: Vienna, Austria, 1994; pp. 209-254.

6. Naulier, M.; Savard, M.M.; Bégin, C.; Marion, J.; Arseneault, D.; Bégin, Y. Carbon and oxygen isotopes of lakeshore black spruce trees in northeastern Canada as proxies for climatic reconstruction. Chem. Geol. 2014, 374-375, 37-43. [CrossRef]

7. Leketa, K.; Abiye, T.A. Investigating stable isotope effects and moisture trajectories for rainfall events in Johannesburg, South Africa. Water Sa 2020, 46, 429-437.

8. Kebede, S.; Travi, Y. Origin of the $\delta 18 \mathrm{O}$ and $\delta 2 \mathrm{H}$ composition of meteoric waters in Ethiopia. Quat. Int. 2012, 257, 4-12. [CrossRef]

9. Rozanski, K.; Araguas-Araguas, L.; Gofiantini, R. Isotopic patterns in modern global precipitation, in Climate Change in Continental Isotopic Records. Geophys. Monogr. Ser. 1993, 78, 1-36.

10. Gofiantini, R.; Zuppi, G.M.; Eccles, D.H.; Ferro, W. Isotope investigation of Lake Malawi. In Isotopes in Lake Studies; International Atomic Energy Agency: Vienna, Austria, 1994. Available online: https://inis.iaea.org/search/search.aspx?orig_q=RN:12581226 (accessed on 15 March 2021).

11. Kalebe, Y.N. Chemical and Isotopic Composition of Thermal Waters in Northern Part of Malawi. Available online: https: / / orkustofnun.is/gogn/unu-gtp-report/UNU-GTP-2017-13.pdf (accessed on 11 December 2020).

12. Kambuku, D.; Tsujimura, M.; Kagawa, S. Groundwater recharge and flow processes as revealed by stable isotopes and geochemistry in fractured Hornblende-biotite-gneiss, Rivirivi Catchment, Malawi. Afr. J. Environ. Sci. Technol. 2018, 12, 1-14.

13. Kambuku, D.; Tsujimura, M.; Kagawa, S.; Mdala, H. Corroborating stable isotopic data with pumping test data to inves-tigate recharge and groundwater flow processes in a fractured rock aquifer, Rivirivi Catchment, Malawi. Environ. Earth Sci. 2018, 77, 226. [CrossRef]

14. Mapoma, H.W.T.; Xie, X.; Zhang, L. Redox control on trace element geochemistry and provenance of groundwater in fractured basement of Blantyre, Malawi. J. Afr. Earth Sci. 2014, 100, 335-345. [CrossRef]

15. Missi, C.; Atekwana, E.A. Physical, chemical and isotopic characteristics of groundwater and surface water in the Lake Chilwa Basin, Malawi. J. Afr. Earth Sci. 2020, 162, 103737. [CrossRef]

16. Monjerezi, M.; Vogt, R.D.; Aagaard, P.; Gebru, A.G.; Saka, J.D. Using $87 \mathrm{Sr} / 86 \mathrm{Sr}, \delta 18 \mathrm{O}$ and $\delta 2 \mathrm{H}$ isotopes along with major chemical composition to assess groundwater salinization in lower Shire valley, Malawi. Appl. Geochem. 2011, 26, 2201-2214. [CrossRef]

17. Spigel, R.; Coulter, G. Comparison of Hydrology and Physical Limnology of the East African Great Lakes: Tanganyika, Malawi, Victoria, Kivu and Turkana (with reference to some North American Great Lakes). In the Limnology, Climatology and Paleoclimatology of the East. African Lakes; Roulege: London, UK, 2019; pp. 103-139. [CrossRef]

18. Balagizi, C.M.; Kasereka, M.M.; Cuoco, E.; Liotta, M. Influence of moisture source dynamics and weather patterns on stable isotopes ratios of precipitation in Central-Eastern Africa. Sci. Total. Environ. 2018, 628-629, 1058-1078. [CrossRef]

19. Kululanga, G.K.; Chavula, G.M.S. National Environmental Action Plan-A Report on Water Resources; Ministry of Research and Environmental Affairs: Lilongowe, Malawi, 1993.

20. JMP. Progress on Sanitation and Drinking Water, 2012 Update; WHO: Geneva, Switzerland; UNICEF: New York, NY, USA, 2015. Available online: http:/ / www.wssinfo.org/ (accessed on 27 October 2020).

21. Upton, K.; OÓ Dochartaigh, B.E.; Chunga, B.; Bellwood-Howard, I. Africa Groundwater Atlas: Hydrogeology of Malawi 2016. Available online: http:/ / earthwise.bgs.ac.uk/index.php/Hydrogeology_of_Malawi (accessed on 23 March 2018).

22. Kalin, R.M.; Mwanamveka, J.; Coulson, A.B.; Robertson, D.J.C.; Clark, H.; Rathjen, J.; Rivett, M.O. Stranded Assets as a Key Concept to Guide Investment Strategies for Sustainable Development Goal. Water 2019, 11, 702. [CrossRef]

23. Rivett, M.O.; Budimir, L.; Mannix, N.; Miller, A.V.; Addison, M.J.; Moyo, P.; Wanangwa, G.J.; Phiri, O.L.; Songola, C.E.; Nhlema, M.; et al. Responding to salinity in a rural African alluvial valley aquifer system: To boldly go beyond the world of hand-pumped groundwater supply? Sci. Total. Environ. 2019, 653, 1005-1024. [CrossRef]

24. Jin, Z.; Ainsworth, E.A.; Leakey, A.D.B.; Lobell, D.B.L. Increasing drought and diminishing benefits of elevated carbon dioxide for soybean yields across the US Midwest Glob. Chang. Biol. 2018, 24, e522-e533. [CrossRef]

25. Serdeczny, O.; Adams, S.; Baarsch, F.; Coumou, D.; Robinson, A.; Hare, W.; Schaeffer, M.; Perrette, M.; Reinhardt, J. Climate change impacts in Sub-Saharan Africa: From physical changes to their social repercussions. Reg. Environ. Chang. 2017, 17, 1585-1600. [CrossRef]

26. Lumbroso, D.M.; Woolhouse, G.; Jones, L. A review of the consideration of climate change in the planning of hydropower schemes in sub-Saharan Africa. Clim. Chang. 2015, 133, 621-633. [CrossRef] 
27. Clark, I.D.; Fritz, P. Environmental Isotopes in Hydrogeology; Informa UK Limited: London, UK, 2013; p. 328.

28. IAEA. Atlas of Isotope Hydrology —Africa; International Atomic Energy Agency: Vienna, Austria, 2007.

29. Trocaire. Climate Change Case Study, Malawi. 2015. Available online: http://www.trocaire.org/sites/trocaire/files/resources/ policy / malawi-climate-change-case-study.pdf (accessed on 23 March 2018).

30. Bernard, B.; Vincent, K.; Frank, M.; Anthony, E. Comparison of extreme weather events and streamflow from drought indices and a hydrological model in River Malaba, Eastern Uganda. Int. J. Environ. Stud. 2013, 70, 940-951. [CrossRef]

31. Niang, I.; Ruppel, O.C.; Abdrabo, M.A.; Essel, A.; Lennard, C.; Padgham, J.; Urquhart, P. Africa. In Climate Change: Impacts, Adaptation, and Vulnerability. Part. B: Regional Aspects. Contribution of Working Group II to the Fifth Assessment Report of the Intergovernmental Panel on Climate Change; Barros, V.R., Field, C.B., Dokken, D.J., Eds.; Cambridge University Press: Cambridge, UK, 2014; pp. 1199-1265.

32. Egeru, A.; Osaliya, R.; MacOpiyo, L.; Mburu, J.; Wasonga, O.; Barasa, B.; Said, M.; Aleper, D.; Mwanjalolo, G.-J.M. Assessing the spatio-temporal climate variability in semi-arid Karamoja sub-region in north-eastern Uganda. Int. J. Environ. Stud. 2014, 71, 490-509. [CrossRef]

33. AFIDEP; PAI. Population Dynamics, Climate Change and Sustainable Development in Malawi; African Institute for Development Policy: Washington, DC, USA, 2012.

34. Coulibaly, J.Y.; Mbow, C.; Sileshi, G.W.; Beedy, T.; Kundhlande, G.; Musau, J. Mapping Vulnerability to Climate Change in Malawi: Spatial and Social Differentiation in the Shire River Basin. Am. J. Clim. Chang. 2015, 04, 282-294. [CrossRef]

35. Kambombe, O.; Odongo, V.; Mutual, B.; Wambua, R. Impact of climate variability and land use change on streamflow in lake Chilwa basin, Malawi. Int. J. Hydrol. 2018, 2, 364-370.

36. Fraser, C.M.; Kalin, R.M.; Rivett, M.; Nkhata, M.; Kanjaye, M. A national approach to systematic transboundary aquifer as-sessment and conceptualisation at relevant scales: A Malawi case study. J. Hydrol. Reg. Stud. 2018, 20, 35-48. [CrossRef]

37. Kotir, J.H. Climate change and variability in Sub-Saharan Africa: A review of current and future trends and impacts on agriculture and food security. Environ. Dev. Sustain. 2010, 13, 587-605. [CrossRef]

38. IPCC. Climate Change: Synthesis Report. Contribution of Working Groups I, II and III to the Fifth Assessment Report of the Intergovernmental Panel on Climate Change; Pachauri, R.K., Meyer, L.A., Eds.; IPCC: Geneva, Switzerland, 2014; p. 151.

39. Banda, L.C.; Rivett, M.O.; Kalin, R.M.; Zavison, A.S.; Phiri, P.; Kelly, L.; Chavula, G.; Kapachika, C.C.; Nkhata, M.; Kamtukule, S.; et al. Water-Isotope Capacity Building and Demonstration in a Developing World Context: Isotopic Baseline and Conceptualization of a Lake Malawi Catchment. Water 2019, 11, 2600. [CrossRef]

40. Banda, L.C.; Rivett, M.O.; Kalin, R.M.; Zavison, A.S.K.; Phiri, P.; Chavula, G.; Kapachika, C.; Kamtukule, S.; Fraser, C.; Nhlema, M. Seasonally Variant Stable Isotope Baseline Characterisation of Malawi's Shire River Basin to Support Integrated Water Resources Management. Water 2020, 12, 1410. [CrossRef]

41. Smith-Carrington, A.K.; Chilton, P.J. Groundwater Resources of Malawi. Overseas Development Administration Institute of Geological Sciences. Available online: http:/ / resources.bgs.ac.uk/sadcreports/malawi1983smithcarringtonmalawigwresources pdf (accessed on 20 March 2021).

42. Nicholson, S.E.; Klotter, D.; Chavula, G. A detailed rainfall climatology for Malawi, Southern Africa. Int. J. Clim. 2014, 34, 315-325. [CrossRef]

43. Kumbuyo, C.P.; Yasuda, H.; Kitamura, Y.; Shimizu, K. Fluctuation of rainfall time series in Malawi: An analysis of selected areas. Geofizika 2014, 31, 13-28. [CrossRef]

44. Vincent, K.; Dougill, A.J.; Mkwambisi, D.D.; Cull, T.; Stringer, L.C.; Chanika, D. Analysis of Existing Weather and Climate Information for Malawi; Kulima Integrated Development Solutions: Pietermaritzburg, South Africa, 2014.

45. Department of Climate Change and Meteorological Services. Available online: http:/ /www.rvatlas.org (accessed on 18 November 2020).

46. Ngongondo, C.; Xu, C.-Y.; Gottschalk, L.; Alemaw, B. Evaluation of spatial and temporal characteristics of rainfall in Malawi: A case of data scarce region. Theor. Appl. Clim. 2011, 106, 79-93. [CrossRef]

47. Hatvani, I.G.; Szatmári, G.; Kern, Z.; Erdélyi, D.; Vreča, P.; Kanduč, T.; Czuppon, G.; Lojen, S.; Kohán, B. Geostatistical evaluation of the design of the precipitation stable isotope monitoring network for Slovenia and Hungary. Environ. Int. 2021, 146, 106263. [CrossRef]

48. IAEA/GNIP (International Atomic Energy Agency/Global Network of Isotopes in Precipitation). Precipitation Sampling Guide; International Atomic Energy Agency: Vienna, Austria, 2014. Available online: http://www-naweb.iaea.org/napc/ih/IHS_ resources_gnip.html (accessed on 15 December 2020).

49. Boschetti, T.; Cifuentes, J.; Iacumin, P.; Selmo, E. Local Meteoric Water Line of Northern Chile ( $18^{\circ}$ S-30 3 ): An Application of Error-in-Variables Regression to the Oxygen and Hydrogen Stable Isotope Ratio of Precipitation. Water 2019, 11, 791. [CrossRef]

50. Craig, H. Isotopic Variations in Meteoric Waters. Science 1961, 133, 1702-1703. [CrossRef]

51. Rozanski, K.; Araguás-Araguás, L.; Gonfiantini, R. Isotopic Patterns in Modern Global Precipitation. Large Igneous Provinces 2013, 78, 1-36.

52. Dansgaard, W. Stable isotopes in precipitation. Tellus 1964, 16, 436-468. [CrossRef]

53. IAEA (International Atomic Energy Agency). Laser Spectroscopic Analysis of Liquid Water Samples for Stable Hydrogen and Oxygen Isotopes; Training Course Series No. 35; International Atomic Energy Agency: Vienna, Austria, 2009. Available online: https://www. iaea.org/publications / 8195/laser-spectroscopic-analysis-of-liquid-water-samples-for-stable-hydrogen-and-oxygen-isotopes (accessed on 8 November 2019). 
54. Gat, J.R.; Matsui, T.J. Atmospheric water balance in the Amazon Basin: An isotopic evapotranspiration model. Geophys. Res. 1991, 96, 13179-13188. [CrossRef]

55. Stewart, M.K. Stable isotope fractionation due to evaporation and isotopic exchange of falling waterdrops: Applications to atmospheric processes and evaporation of lakes. J. Geophys. Res. 1975, 80, 1133-1146. [CrossRef]

56. Salamalikis, V.; Argiriou, A.; Dotsika, E. Isotopic modeling of the sub-cloud evaporation effect in precipitation. Sci. Total. Environ. 2016, 544, 1059-1072. [CrossRef] [PubMed]

57. Aggarwal, P.K.; Gat, J.R.; Froehlich, K. (Eds.) Isotopes in the Water Cycle, Past, Present and Future of a Developing Science; Springer: Dordrecht, The Netherlands, 2005.

58. Gonfiantini, R.; Roche, M.-A.; Olivry, J.-C.; Fontes, J.-C.; Zuppi, G.M. The altitude effect on the isotopic composition of tropical rains. Chem. Geol. 2001, 181, 147-167. [CrossRef]

59. Kern, Z.; Hatvani, I.; Czuppon, G.; Fórizs, I.; Erdélyi, D.; Kanduč, T.; Palcsu, L.; Vreča, P. Isotopic 'Altitude' and 'Continental' Effects in Modern Precipitation across the Adriatic-Pannonian Region. Water 2020, 12, 1797. [CrossRef]

60. Wirmvem, M.J.; Ohba, T.; Kamtchueng, B.T.; Taylor, E.T.; Fantong, W.Y.; Ako, A.A. Variation in stable isotope ratios of monthly rainfall in the Douala and Yaounde cities, Cameroon: Local meteoric lines and relationship to regional precipitation cycle. Appl. Water Sci. 2017, 7, 2343-2356. [CrossRef]

61. Lawrence, J.R.; Gedzelman, S.D.; Gamache, J.; Black, M. Stable Isotope Ratios: Hurricane Olivia. J. Atmos. Chem. 2002, 41, 67-82. [CrossRef]

62. Durowoju, O.; Butler, M.; Ekosse, G.-I.; Odiyo, J. Hydrochemical Processes and Isotopic Study of Geothermal Springs within Soutpansberg, Limpopo Province. S. Afr. Appl. Sci. 2019, 9, 1688. [CrossRef] 